\title{
Interventions and Allies
}

During the 1980s, LSM/al-Haq developed and systematized its working methodologies and tightened its articulation of its priorities in response to developments in Israel's declared policy and documented practice. The basis, however, remained the understanding that serious violations of civil and political rights by the occupation authorities were committed in the service of pursuing a primary annexationist agenda. For legal analysis and underpinning of appeals to third parties, LSM/al-Haq moved from early invocations of the Universal Declaration of Human Rights (UDHR), on the one hand, and international humanitarian law (IHL) on the other (the Fourth Geneva Convention 1949 and the Hague Regulations 1907), and began looking also at international human rights instruments, at this stage for their moral and declaratory authority. The organization experimented with formats through which to publicize its findings, with the hope of prompting cessation or correction of the violations addressed. In the 1986 Programme Report-a lengthy document that demonstrates ongoing reflection on the work to date-al-Haq stated that the organization

undertakes to detect, document and investigate human rights violations; to look for and identify patterns of violations and to investigate their antecedents and causes; to inform and educate individuals, groups, governments and international bodies regarding the facts, and their rights and obligations under law in the presence of those facts, as well as to consider their actions in the light of universal legal and human rights principles; and to challenge legislative acts and practices which contravene or prejudice the principles and rights which al-Haq seeks to uphold.

The critical question of "impact" currently being asked of all human rights organizations (by donors, by constituencies) may not have been phrased in quite the same way, but al-Haq's approach, both pragmatic and strategic, meant that the question of "what works" very much defined what it did with the information held through its fieldwork and legal research, as well as informing the direction 
and methodologies of this research. Field and legal research and interventions are identified in the 1986 report as the "core programme."

This chapter considers how the different elements of al-Haq's core program worked together. This includes how it developed and deployed what it termed interventions, how it sought to mobilize and work with allies, and the particular form and fate of its Enforcement Project.

\section{INTERVENTIONS}

As already noted, by $1984 \mathrm{LSM} / \mathrm{al}-\mathrm{Haq}$ had an established practice of making interventions to identified persons with particular responsibilities for and authority over different aspects of life in the West Bank. Although this is now considered a standard form of human rights work, it was not then, nor was the decision to incorporate it as part of LSM's methodology straightforward or taken in one go. According to Emma Playfair:

It seems obvious now, you write to those responsible and put the case and await a response, on the record. But then, it was really weird. [ . . . ] Any contact with the occupier was seen as immoral; it wasn't done then.

The first intervention was made in $1983 .{ }^{1}$ Sami 'Ayad fieldwork coordinator at the time, recalls discussions about

how to frame it, addressing the occupying power whose very presence you reject. You denounce the violation on the basis of evidence and give a list of demands for improvement, based on their obligations, military orders, etc. For example, the treatment of prisoners: you object to the prisons, but you demand action from the authorities. We were very careful who we addressed-the minister of defense, the military governor, for example. You have a relationship with the occupying power which you object to in the first place.

A draft document of Programme Objectives for 1987 defines both an "activist" and a "promotional" role for al-Haq, addressing both the local and the international communities. The first address under the activist heading is interventions with the Israeli government and military authorities, which the organization states it is undertaking in order "to redress and inhibit specific violations, provoke disclosure of information, elicit clarification of the criteria used by its personnel in actions taken vis-à-vis the local population and the implicit and explicit policies implemented in the Occupied Territories." An explanation of what goes into the making of an intervention begins with the organization's critical reliance on documentation:

When satisfied that a particular action constitutes a violation of a legal principle and after all relevant facts have been established and properly documented, alHaq addresses the appropriate authorities, and/or requests other organisations and 
individuals to do so. Such interventions include a presentation of the evidence in al-Haq's possession; legal arguments asserting that there has been a violation of a recognised principle and that this must be remedied; and a petition to desist from the offending practice, to provide redress to the victim, to carry out an official investigation, or to provide other relief or action. ${ }^{2}$

By 1986, interventions were grouped into five broad subject areas:

(1) law and structure;

(2) deaths, injuries and harassment ("at the hands of all sections of the Israeli army, the police, Jewish settlers and Israeli-sponsored 'village leagues"');

(3) arrests and detention (including "cases of illegal arrest and detention, prison conditions and harassment of prisoners during and as a result of their detention");

(4) collective punishment (including house demolition and sealing and punitive curfews); and

(5) control measures preventing West Bank residents from "going about their normal business" (these included "restrictions on travel out of the West Bank, withholding of building permits or driving licences, restrictions on leaving a town or district within the West Bank, and closure of trade unions"). ${ }^{3}$

An example of the process was al-Haq's intervention after the use of tear gas in Jnaid prison early in 1987. The organization had made interventions in a number of previous cases of the use of gas against political prisoners in the confined spaces of prisons. When the Jnaid incident happened, "al-Haq was then convinced that its unpublicised efforts to persuade the Israeli military authorities to stop this inhumane practice had failed" and it therefore "felt compelled to publicise its concern." Al-Haq issued a press release (which was censored by the Israeli authorities who barred the Arabic press from publishing it); this was attached to the Newsletter, which carried news of this intervention. ${ }^{4}$

In 1986 al-Haq reported nearly eighty interventions to date, which had met with "varying degrees of success."5 The Draft Programme Objectives for 1987 noted that "despite al-Haq's disappointment at its past lack of success it plans to continue its efforts in this area, while at the same time seeking support from local and international partners who can assist." This had often been a feature of interventionsLSM would send a letter to the military authorities and a copy to the ICJ or to Amnesty, for example, or to ACRI, or would seek their direct intervention in a case or an issue within their mandate. The thinking around such appeals to allies was developing strategically in parallel with the organization's frustration or "disappointment." In his paper for the 1988 al-Haq conference, Jonathan Kuttab acknowledged the difference that an individual Israeli officer might make but noted that "such appeals are rarely effective, and have become even less so in recent times." 
He also noted a change in practice on the part of "different constituent parts of the military government, and the civilian administration, to refer any complicated or controversial issue to the office of the legal adviser." He observed:

To the extent that the holder of that office was conversant with international humanitarian law, and valued the concept of the rule of law, such appeals could be useful. At least a reasoned response would be forthcoming that is aware of the possibility of adverse publicity in case of a totally unintelligent response. For this reason it became an almost routine procedure for al-Haq, after carefully investigating and adequately documenting a human rights violation that came to its attention first to write a carefully worded intervention to the legal adviser, and await his response, both as to the factual accuracy of our statements, and for his legal response to the arguments we make.

Unfortunately, the present staff of the legal adviser's office do not seem to be concerned about the rule of law, and protection of human rights. Their responses are very delayed, perfunctory, and lacking in substance. [ . . . ] We can no longer see in the legal adviser, even remotely, a possible avenue for redress. ${ }^{6}$

While continuing to place facts and petitions on record, al-Haq was developing its network of allies among Israeli lawyers and human rights activists and in the international community. It framed a theory of international protection or, more specifically, addresses to which appeals for third-party state intervention with the Israeli authorities might be made, on an international law basis, by members of the civilian Palestinian population of the occupied territories. In January 1988, at the beginning of the first intifada, al-Haq addressed its first such appeal directly to High Contracting Parties to the Fourth Geneva Convention.

Before this, the only communication with a third-party state made by LSM that could be classed as an intervention had been two responses to the chapter on Israel and the occupied territories in the Country Reports on Human Rights Practices prepared by the US State Department for the US Congress covering the years 1982 and 1984. The idea of preparing the response seems to have come from groups in the United States, ${ }^{8}$ and the drafter of the first observes:

I do think there was some belief that the human rights reports were 'evidence-based' and by supplying evidence there was a possibility that future ones might better reflect reality. [...] As with the other projects, the aim was to produce objectively verifiable "facts" to establish a case-this was very much the LSM philosophy then.

The first LSM Newsletter reported that "we considered it necessary to correct the erroneous impression of the human rights situation as found by the American report, through critiquing and responding to it section by section." 9 The LSM response was sent via the US consul general in Jerusalem and included a letter to the US secretary of state noting that LSM had found "certain omissions and misrepresentations" and expressing the hope that "the information and observations 
contained in LSM's reply will be given careful consideration by you and your staff in the course of preparing the report for 1983, and that any necessary amendments to the 1982 Report be made for the record." ${ }^{10}$ It was not to be long before LSM realized that this hope was overly ambitious, if not entirely misplaced: the US authorities had no intention of amending their own reports, particularly on Israel, simply in light of facts presented.

LSM's response to the 1982 US report opened with the "immense amount of US aid to Israel [ . . . ] which enables, for example, Israel to finance the expansion of its settlement programme in the occupied territories" and explains that the fact that "decisions on the granting of US aid are, by law, dependent on the human rights report" was the reason for LSM preparing its response. ${ }^{11}$ Among the features that LSM particularly objected to were the absence of context, the "practice of recording Israeli opinions and government statements as facts, while referring to any information provided by Palestinians as 'allegations' and 'complaints,'” and the impression that actions by Israeli actors that violate Palestinian human rights are "in response to supposed acts of Palestinian terrorism and as such are understandable." The LSM response continues:

The word terrorism is mentioned seven times in the Report, although a thorough review of the Israeli press during 1982 fails to find these acts of terrorism, unless the definition is to be greatly expanded to include groups of stone-throwing students, commercial strikes, and peaceful demonstrations. ${ }^{12}$

Skipping the State Department's Country Report for 1983, al-Haq published a second response on the report for 1984, a document in a rather different style. This time, the New York-based Lawyers' Committee for Human Rights (LCHR) had asked al-Haq to prepare a response, which LCHR then sent to the State Department endorsing al-Haq's conclusions, and met with the US assistant secretary of state for human rights; al-Haq also sent its response itself to the State Department. ${ }^{13}$ In the preface to al-Haq's response, Hiltermann writes:

In this reply [ ... ] al-Haq concluded that, although the State Department had somewhat improved the content of its report compared with previous years by paying more attention to detail and correcting at least some of the errors al-Haq had pointed out in its earlier critique, a number of serious distortions and omissions of vital areas of the human rights situation in the Occupied Territories continued to undermine the Report's value. [ . . . ] Al-Haq's purpose in making public a written reply to the State Department's human rights report on this occasion was not so much to point out all individual errors committed by the Report's authors, as it had done in the 1983 reply, but to place the errors in their conceptual context: Why were such errors permitted to recur over and again? And why did al-Haq's previous critique, and critiques provided by other parties, have so little impact on the accuracy of subsequent State Department reports, or-in light of Israel's record in the area of human rights, described in these reports-on the continued high level of US economic and military aid to Israel in general? ${ }^{14}$ 
The context as presented by al-Haq included a proposed dramatic increase in economic and military aid to Israel, the creation of new settlements and "thickening" of existing ones, deterioration in prison conditions, an increase in settler aggression, and the entrenchment of the dual system of law "as exemplified by a military directive issued in 1984 which made it impossible for Palestinians to register complaints against Israeli citizens in the West Bank without a permit from the military authorities." 15 The response refers to "a political climate in Israel that is profoundly unfavourable to discussing Israeli practices in the West Bank and Gaza, let alone the Occupied Territories' final status. As a result the status quo is allowed to further evolve, bringing ever closer the day that the annexation of the West Bank and Gaza will be accomplished all but in name." The mode of reporting includes placing "Palestinians and Israelis on an equal level in terms of their conduct and/ or the violence to which they are exposed." The Report persists in referring to "information provided by Palestinians as 'claims', 'allegations' or 'complaints' while the Israeli authorities 'state"'; there are serious problems with presenting the Israeli authorities' claims that they do not condone political killing, and a downplaying of the economic, social, and cultural situation in the occupied territories-here the response quotes then Israeli minister of defense Yitzhak Rabin as stating that "there will be no development [in the territories] initiated by the Israeli government, and no permits will be given for expanding agriculture or industry [there], which may compete with the State of Israel." ${ }^{16}$ Omissions include the introduction of Jewish settlers in the occupied territories, and collective punishment imposed "in retaliation for individual acts of resistance by Palestinians." There is also the major contextual issue of Israel's military occupation which "combines repression with economic exploitation to deprive the Palestinian population of its most fundamental, inalienable rights":

\begin{abstract}
The report's orientation is in keeping with the traditional western definition of human rights as individual political rights, at the risk of ignoring such collective rights as the right to social and economic development, which the US government is "not prepared to recognize as a basic human right" (p. 7). This makes it possible for the report's authors to gloss over the impact of Israel's growing control of land and water resources, the building of new settlements, the denial of trade permits and licenses to set up industrial enterprises, and collective punishmentwhich are indeed key features of the violations of human rights suffered by the Palestinian population. ${ }^{17}$
\end{abstract}

The structural link to context and insistence on collective social and economic rights are key features of al-Haq's analysis, and the development in the nature of its response is evidence of an organization critically examining the impact of its past intervention. Al-Haq informs its readers that having pointed out "empirical and conceptual errors" in its two responses to the US Reports, and "in the absence of a substantive change in the State Department's reporting," the organization "has now decided that it would not be productive to compose a critical reply to the 
annual human rights report on a yearly basis."18 This was an organization critically examining the impact of its past interventions and adopting a pragmatic response.

Al-Haq went on to issue three more public responses, against the changed and charged background of the first intifada, for the years 1989, 1990, and 1991. After this, it was to be more than fifteen years before al-Haq would publicly intervene again with the US State Department on the contents of its Country Report for Israel and the Occupied Territories, in the aftermath of the 2008-9 war on Gaza. This intervention was made in the form of a letter sent by al-Haq and sixteen other Palestinian and non-Palestinian organizations on the subject of the preparation of the US report for the year 2009. ${ }^{19}$ In particular, this intervention invoked findings of "gross and massive violations of human rights constituting war crimes and possibly crimes against humanity" made public in the reporting period (2009), focusing especially on the Report of the UN Fact-Finding Mission to Gaza, mandated by the Human Rights Council (the "Goldstone report") after Israel's assault on Gaza in December 2008-January 2009. ${ }^{20}$ The charge of war crimes and crimes against humanity are significant features of the current Palestinian NGO human rights discourse, and were arguably pioneered in Al-Haq's work on grave breaches of the Fourth Geneva Convention at the end of the 1980s.

There is another point to note about this intervention: the letter is addressed to Michael Posner, who for just over two months had been assistant secretary of state for democracy, human rights and labor in Barack Obama's government, but before that had for some thirty years been the first executive director of LCHR and then of its successor Human Rights First; it was under his leadership that LCHR had requested a critique of the 1984 State Department report from al-Haq, and it was Posner who played the leading role in LCHR's 1988 report on Israel's detention of four al-Haq field-workers along with two Gazan lawyers. ${ }^{21}$ "We were gratified to learn," says the 2009 letter, "that someone with your human rights advocacy record has taken the helm of this important section of the State Department."

This kind of intervention was, however, the exception in al-Haq's earlier years. Most were addressed to the relevant military government authority responsible for the violation. The first Newsletter details interventions made to the Israeli minister of defense, with copies to the attorney general and the Knesset State Control Committee, regarding the fact that there was no system of judicial appeal against the decisions of Israeli military courts in the West Bank; and to the Minister of Defense, the attorney general and the coordinator of activities in the occupied territories seeking a full police investigation into the placing of "bombs or other explosive devices" at schools in the Ramallah district, coinciding with slogans and death threats on school walls "accompanied by the name 'Terror against Terror' and a number of Israeli flags." ${ }^{22}$ It also reported a response to an intervention it had made in June 1983 and in March 1984 to other human rights organizations locally and internationally, as well as to the military authorities, on the subject of the arrest of secondary school students during the period of their tawjihi ("matriculation") 
exams concluding their high school education. LSM/al-Haq reported receipt of a copy of a letter sent by the office of the coordinator of activities in the occupied territories to the Israeli human rights group ACRI who had addressed him on the basis of the information sent by LSM. The official cited "security reasons" and insisted that it was "pure coincidence that the arrests occurred at the time of the tawjihi exams." 23

Al-Haq was to continue following the issue of tawjihi arrests for the next few years, seeking inter alia to establish that they were anything but coincidental. Sami 'Ayad recalls the efforts made by LSM to establish systematic intent on the part of the Israeli authorities to cause these students to miss their final exams: "We collected lots of information, in different years and different places where the students were arrested. Sometimes there was no demonstration [going on at the time]. There were surprise detentions at exam time. It showed that there was a methodological intent in targeting them." The Introduction to a 1986 Newsletter, titled "Al-Haq's Action to Defend the Right to Education," reviewed al-Haq's efforts in regard to this practice from 1983, including communications by ACRI, the ICJ in Geneva, and Amnesty International. ${ }^{24} \mathrm{Al}$-Haq had not received responses itself, but considered that it had achieved its objective of making this violation better known. It had been heartened by the decrease in numbers of reports of such arrests: "Despite the fact that it was clear from its enquiries that students are in fact still being arrested without either interrogation or charge, it still had reason to hope that its efforts and those of other human rights organizations locally and abroad had led to the end of this particular type of arrest." It had noted substantial decreases in the reported numbers and had had no reports for late 1985-86. In the meantime, alHaq reported that in 1984 the organization "had a discussion with the Legal Advisor to the civilian Administration as to how it should deal with urgent matters. An agreement was reached whereby in urgent cases al-Haq could make quick contact by telephone or telegram so as to get immediate response to enable a violation to be halted before any permanent harm was done." When it learned, therefore, of further such arrests in 1986, the organization sent a telegram to the legal adviser in accordance with the agreement that had been reached, "but the response was by a letter received only when it was already too late for the students to sit their exams." It also then began to learn of other, unreported tawjihi arrests in previous years. ${ }^{25}$ Al-Haq reflected on what might now be called a "small win" as follows:

It is true that al-Haq was able through its efforts to reduce the number of students arrested from 38 in 1983 to 8 in this year. However, it had hoped that the violation would stop entirely, especially after it became well-known and documented. This hope was not realised. Despite a low number of student arrests this year in comparison with other years, this cannot be considered as a final resolution of the violation.

This sequence of events has caused al-Haq to reflect on its expectations of progress in defending human rights in the Occupied Territories, and on its mode of operation. 
Reflections such as the above are always necessary. The organization must continually reassess the manner in which it works, if it is to seek with all means available to find the best way to fulfill the objectives or tasks for which it was established, and refuse to accept the continuation of any violation, whatever its origin. ${ }^{26}$

The issue of the malicious arrest of tawjihi students was updated in the following Newsletter, but it was quite shortly to be overtaken by the closure of all educational institutions in the West Bank-and prohibiting of alternative arrangements for education-in response to the first intifada, described by al-Haq in 1988 as Israel's "war on education." ${ }^{27}$ The interventions on the tawjihi arrests illustrate a number of features of al-Haq's intervention methods, including the difference that a change in personnel at particular Israeli officer posts (such as legal adviser) could bring. They also illustrate what Kuttab describes after the raid on the first LSM office in 1982; LSM wrote a letter of four paragraphs to the military authorities setting out their concerns (as recalled in chapter 3 ) and copied the letter to Haim Cohn, who wrote a letter of three paragraphs to inquire about the matter. "Some very high-level officers came, and they had very specific instructions to investigate and answer each of the three paragraphs; they didn't care what we wrote, but they cared what Haim Cohn wrote, they didn't even have a copy of our letter, it was his. It was a lesson for us: it matters who you write to."

Both ACRI and the Israeli section of the ICJ-or more specifically Haim Cohn-were early recipients of LSM's interventions, which were copied to these Israeli organizations that were more likely than LSM to get a response if they raised the issues with Israeli authorities. Less formally, Raja Shehadeh recalls regular meetings in the early 1980s with ACRI, the Jerusalem office of Quaker Peace and Service, and the ICRC. According to Shehadeh, it was during these meetings that ACRI became interested in the issue of settler violence and harassment against Palestinian civilians and property in the West Bank, and particularly on the issue of the apparent lack of proper investigation of such incidents by the police or military authorities. ACRI did not at that time work on the occupied territories, and at a retreat for human rights NGO leaders in Crete in 1989, a board member indicated the dilemmas the organization felt it still faced in choosing to get more involved, or on the other hand in choosing not to. ${ }^{28}$ Back in 1981, the Israeli attorney general had appointed a commission of inquiry under the leadership of the deputy attorney general Yehudit Karp; her report, submitted in spring 1982 but not published until 1984, showed that of seventy cases of "murder, damage to property and vigilante activities allegedly by settlers," only fifteen had been investigated by police. ${ }^{29}$ By 1985 , Raja Shehadeh, who had given evidence to the State Control Committee of the Knesset on the West Bank legal system following publication of the Karp report, was recording still no action on its recommendations. ${ }^{30}$ LSM/ al-Haq continued to make interventions to the military authorities, for example a letter to the military commander of the Central Area in July 1987 following a raid 
by around two hundred armed Israeli settlers on the Palestinian refugee camp of Dheisha near Bethlehem..$^{31}$ The organization did not, however, publish separately on this subject until the annual reports of the first three years of the intifada, each of which contained a chapter on violence by Israeli settlers. Besides documenting the facts of different settler-related incidents, al-Haq's interventions stressed the issues of accountability and the development of two separate legal systems in the West Bank. In its intervention on the 1987 incident in Dheisha camp, for example, the organization asked the following questions:

1. What are the criteria used by the authorities in arming civilians in the West Bank, and what precautions are taken, if any, to ensure that they will not misuse their weapons?

2. Are the authorities investigating the reaction of the armed forces to the raid in order to establish whether or not they performed their duties according to international law?

3. Why was a 24-hour curfew imposed [on the camp], one camp entrance closed, and a high fence erected along one side of the camp following incidents which were provoked by the raid by Kiryat Arba settlers on the camp?

4. Why are the settlers who were arrested being tried in an Israeli court in Jerusalem, and not in the West Bank, despite the fact that the raid took place in the West Bank and the settlers are living in the West Bank?32

Other indications of LSM/al-Haq's rule-of-law focus include interventions in relation to the arrest or ill-treatment of lawyers, its monitoring and reporting on changes to the legal system, and its pursuit of the need for a professional body for lawyers in the West Bank. The first part of The West Bank and the Rule of Law, it will be recalled, was on "The Judiciary and the Legal Profession," and besides the professional engagement of both Shehadeh and Kuttab with the legal system, the organization had demonstrated a consistent commitment to the protection of an independent judicial profession under occupation. This included interventions on the discriminatory treatment of West Bank lawyers to which LSM objected as arising from Military Order 145, which allowed Israeli lawyers to practice in West Bank courts. ${ }^{33}$ It also included a sustained interest in the establishment of an independent bar association for working West Bank lawyers who had been struck off or (if more recently qualified) were unable to join the Jordanian Bar Association. In this matter, there was a small win for the profession in the autumn of 1987. The Israeli High Court of Justice ruled on a 1984 petition from a group of West Bank lawyers asking that the military authorities be ordered to show cause why a bar association should not be permitted to establish itself in the West Bank. Al-Haq's Newsletter led with this judgment, providing a background of the petition, the strike, the provision under Jordanian law for a bar association, and the usurpation of the authorities of a bar association under Military Order 1164 in 1986 while the West Bank lawyers' petition was still pending at the High Court. 
The order purported to establish a "Lawyers Council Bar Association under the direction of the Civilian Administration"; the latter would assume all powers of appointment and regulation of all financial matters internal to such an association. ${ }^{34} \mathrm{Al}-\mathrm{Haq}$ had intervened with the minister of defense, while the West Bank petitioners maintained their petition to the High Court, arguing, among other things, that establishment of an independent bar association "did not harm any military interest" and was consistent with international legal obligations regulating an occupying power. According to al-Haq's presentation, the military commander responded:

that elections to a professional association did pose a danger to security since in his view all elections in the West Bank are based on the political orientation of the candidates and as such expedite the attempt of "hostile" organisations to enhance their influence over the population.

Possibly because the issue involved a professional legal body, the Israeli High Court did not accept the security argument at face value. Referring to both the "right to organize," even under military occupation, and the need for "due regard to the social order and the security of the state," the ruling concluded:

The Military Commander had not demonstrated that the independence of a bar association, with respect to the issue of the election of council members and control over the council's budget, would threaten security. Moreover, assuming that a "reasonable likelihood" of danger existed, the commander, on the evidence, had not properly weighed the factors involved. Neither had he considered alternative ways of dealing with the anticipated danger while at the same time maintaining, as far as possible, the independence of the new organisation.

Al-Haq gave a partial welcome: "in accordance with our belief in international human rights principles and norms and the rule of law, we see the independence and the proper functioning of the legal profession as an essential cornerstone of these standards" which would not be realized through an association set up under the terms of the military order. In particular, it welcomed the statement regarding the right of association, and the fact that the court had "looked into the issue of whether in exercising his authority and his discretion the Military Commander had weighed the relevant consideration" as a "fundamental principle of administrative justice." Al-Haq warned, however, that this decision was "by no means a victory" since it did not order the military commander to permit the West Bank lawyers to establish a bar association as provided for in Jordanian law. "The matter rests in the Military Commander's hands," concluded al-Haq, "and to date no action has been taken." The Newsletter carrying this article was published at the beginning of January 1988 and promised its readers that the next Newsletter would cover the events of the intifada, which had started on December 9, 1987. Events overtook the ruling on the bar association, and in 1997 the Palestine Bar Association was established under the Palestinian Authority. 
LSM/al-Haq's focus on the legal profession was a key feature of its relationship with the ICJ. Of the international organizations upon whose solidarity al-Haq called in specific interventions, the ICJ was perhaps its most steadfast ally, given the institutional relationship with LSM/al-Haq and the robust attitude of the ICJ's Niall MacDermot. In 1985, an important principle of al-Haq's methodology of intervention - this time, intervention by publication-was to be clarified in acrimonious exchanges at the UN Commission on Human Rights around the report on torture in al-Fara'a prison, copublished by LSM and the ICJ. ${ }^{35}$ One of the complaints made by the Israeli ambassador to the commission was that "prior notice of the report had not been given to the Israeli authorities, and that the ICJ SecretaryGeneral had not disclosed its forthcoming publication to the Israeli Ambassador" when MacDermot had paid the ambassador a courtesy call some days before publication of the report. ${ }^{36}$ Responding in an editorial in the ICJ's Review, MacDermot gave first reply to LSM:

LSM comments "It is not LSM's practice to present its reports to the Israeli government for comment before making them public. We do however make interventions and request specific replies on human rights violations that come to our attention. We address such letters to the Minister of Defence in his capacity as minister with ultimate responsibility for the Military Government of the occupied territories. When a reply is received, which is not always the case, it is only after a long period of time and comes generally from the Legal Advisor to the Civilian Administration of the West Bank. . . . It is precisely because of the gravity of the circumstances related in the report that we are not willing to delay issuing the report while we wait for a response which experience has shown we are unlikely to receive." ${ }^{37}$

For his part, MacDermot explained that he had not felt "at liberty to disclose the forthcoming publication to the Ambassador without prior consultation with LSM" but that he had since told the ambassador that "he considers it would have been preferable to have advised LSM to give a summary of the report to the Israeli authorities before publication and invite their comments." Al-Haq did not alter its practice. Having taken the decision on the (limited) utility and the principle of corresponding with the military authorities to seek clarification of orders, directives, and practice, as well as in regard to the treatment of specific individuals or groups of individuals and events, and to set out its law-based concerns on such matters, al-Haq did not consider that it was in any way bound to follow the practice of other organizations, local or international, in submitting their publications for comment, in this case to the authorities of the occupying power. With the arrival of the Palestinian Authority in the summer of 1994, following the signing of the Israel-PLO Gaza-Jericho agreement, al-Haq was to revisit this practice in relation to the PA, though not in relation to the Israeli authorities. Its first report on PA directives and practice, The Right to Freedom of Assembly, appends the correspondence between al-Haq's coordinator Fateh Azzam and the director-general of the Palestinian Police, Brigadier-General Ghazi al-Jabali, to whom al-Haq had 
presented the draft report "in order to provide him with a further opportunity to express his opinion and address the issues discussed herein." No response was received to this particular request for comment. ${ }^{38}$ The decision to submit the draft to the PA official had been taken after considerable discussion at al-Haq in the tense days of Oslo.

The 1985 report on al-Fara'a prison comprised a set of affidavits from former detainees. One section included three affidavits complaining of seriously inadequate medical care. LSM had in fact raised this before, as reported in its first Newsletter:

LSM has also recently received reports of the involvement of Israeli medical personnel in the ill-treatment of detainees undergoing interrogation at West Bank detention centres. LSM has written to the Israeli Medical Association informing them of the allegations, pointing out the complete incompatibility of such involvement, if true, with all principles of medical ethics, and asking the Association to investigate the matter further. ${ }^{39}$

This straightforward paragraph had behind it a critical organizational challenge. The allegations against members of the professional Israeli medical authority (the IMA) were extremely serious; it was a huge professional issue, and the field-workers worked hard to collect and verify the information. Sami 'Ayad recalls the complexities, for example, of trying to identify as a doctor or nurse a person not known to the prisoner but who warned of the risks of their medical condition. The second Newsletter reported serious developments in the intervening two months. This time al-Haq was more open about specific allegations regarding the involvement of Israeli medical personnel in interrogating prisoners:

The alleged involvement appears to take three forms: 1) Advising the interrogators on particular points of weakness in the detainee's body or health, following an initial medical examination; such points of weakness are then made use of in the interrogation. 2) Advising the interrogators as to the detainee's ability to sustain further interrogation. 3) Advising the detainee that unless he confesses and receives immediate medical attention his health could be permanently impaired. The methods of interrogation reported include beatings and other cruel and degrading treatment. ${ }^{40}$

Having sent its original letter to the IMA at the beginning of May, LSM was awaiting a reply when a press release was issued by the IMA on June 7 and reported in the Hebrew press, "accusing LSM of making malicious, unsubstantiated and libellous accusations against members of the Israeli medical profession" and naming Raja Shehadeh. The president of the IMA wrote back to LSM, in a letter mailed after the press release, and "repeated the allegation of 'slander.' But after stating that it was impossible to imagine an Israeli physician behaving in the way described he expressed readiness on the part of the IMA to investigate the reports if further details were given." By the time the IMA's letter arrived at LSM, the organization had already felt obliged to "respond publicly in order to 
defend the organisation's integrity and that of its co-director" in light of the IMA's press release. LSM issued its own press release attaching the original letter to the IMA and confirming that "LSM does hold prima facie evidence of the practices alleged which will be released if, on completion of its investigations LSM is satisfied that the allegations are well-founded." LSM also sought a public apology from the IMA, and noted in the Newsletter that "both the organisation and $\mathrm{Mr}$ Shehadeh are contemplating legal proceedings against the IMA if a full apology is not received." Neither the accusations to the IMA nor the grievance of LSM and Shehadeh resulted in legal proceedings, but it had been a tense time for LSM/alHaq, which returned to its findings in regard to Israeli medical professionals in the 1985 al-Fara’a report.

In the early summer of 1985, LSM reported receipt of a letter from the IMA president (dated January 28, 1985) informing the organization that the general officer of the IDF Medical Corps had investigated and had found LSM's allegations to be groundless; but that "in future medical staff would be identifiable by their white coats." ${ }^{41}$ While welcoming this undertaking, LSM's response focused on the reliance placed by the IMA president on the fact that to the best of his knowledge no prisoners' complaints on this subject had been raised by the ICRC. His conclusion was that "either the prisoners did not consider the complaints made to be very serious, or that the complaints had no serious basis." Al-Haq's concerns about how the ICRC's role was used by the Israeli authorities in such situations were to grow over the following years and are discussed further below. Its concerns about the role of Israeli medical personnel were taken up by others, including at the UN Committee against Torture during Israel's first appearance there in 1994, and in a dedicated Amnesty International report in 1996.42

Al-Haq continued to monitor the conduct of Israeli medical personnel, particularly in prisons and detention facilities. Early in the intifada, their role was raised in relation to access for the families to official Israeli investigations, including autopsy reports in cases where a family member had died in circumstances arousing suspicion that law enforcement personnel had been involved-notably, deaths in detention. ${ }^{43}$ An overview of how al-Haq worked on what it described as "the main, precedent-setting case" illustrates the significance of its allies in different parts of the human rights movement.

\section{ALLIES}

The treatment of the case of Ibrahim al-Mtour illustrates the significance of the relations al-Haq was building. In this case, a Scottish forensic pathologist had been asked by the detainee's family (via al-Haq, after appeal to the Israeli High Court by the family's Israeli lawyer) to conduct a second autopsy some months after their son had been buried. ${ }^{44} \mathrm{He}$ held that a named prison doctor had committed "prima facie, a serious breach of medical ethics" by following an order 
from the commander of Dhahiriyya Military Detention Center to administer an injection of tranquilizers to the detainee who was at the time bound hand and foot "in an otherwise empty cell" where the commander had used tear gas on him. ${ }^{45}$ Invoking the UN Principles of Medical Ethics (1982) and the Declaration of Tokyo of the World Medical Association (1975), Derrick Pounder recommended that "all the case information should be forwarded to the appropriate Israeli Medical Authorities with a view to initiating disciplinary proceedings" against the doctor and noting a suspicion that unethical practice by prison doctors was "a widespread problem." ${ }^{46}$

Pounder directed this and his other recommendations to four organizations: Amnesty International, Boston-based Physicians for Human Rights (PHR), the American Academy for the Advancement of Science (AAAS), and the Copenhagen-based Committee of Concerned Forensic Scientists (CCFS). PHR and AAAS had sponsored Pounder's visit, and CCFS was involved in sponsoring later interventions. Israeli lawyers (notably Leah Tsemel and Felicia Langer) acted for the family of the deceased in addressing the Israeli authorities and the High Court. Pounder's report was significant not only in itself but for the combined efforts of the Palestinian and Israeli human rights actors and international allies in the professional medical communities, and the courage and determination of the family of the deceased, Ibrahim al-Mtour. Deaths in Israeli detention centers had increased during the first year of the intifada; Joost Hiltermann, who worked on a number of these cases for al-Haq, wrote that it was the occurrence of five such deaths in one week in the summer of 1988 that prompted the development of an approach of seeking "small, step-by-step precedents" in response. ${ }^{47}$ At the end of that year, in its first annual report, al-Haq reported:

Independent investigation into the cause of these deaths has been made impossible by the authorities' refusal in many cases to make public the results of the official investigations (including autopsy reports), and by their refusal to allow independent forensic experts either to be present at the official autopsies or to conduct second autopsies on behalf of the families of the deceased..$^{48}$

By the end of the second year of the intifada, al-Haq was able to report somealbeit mixed-results of the efforts to challenge the official Israeli narrative on these deaths and gain answers around deaths in detention, explaining these efforts as follows: 49

Al-Haq's aim has been, in the first instance, to gain the right for relatives of the deceased to send a representative of their choice to attend the autopsy and to obtain, within a reasonable amount of time, the results of both the autopsy and the investigation into the circumstances of death; and, in the second instance, to discourage excessive use of force by the army and GSS through threat of legal prosecution. Al-Haq's method in accomplishing these aims was to challenge the authorities' findings with expert opinions. ${ }^{50}$ 
Al-Haq had concluded in the second year of the uprising that there was a "state of lawlessness" in the occupied territories. The organization proceeded to methodically review Israeli law and practice and to seek to hold the occupation authorities to the terms they had set themselves. It also reviewed these terms under the standards of IHL, and drew on reports of the UN Special Rapporteur on extrajudicial summary or arbitrary executions. This examination (critical to Israel's claims to be following the rule of law) can in itself be described as "forensic." ${ }^{51}$ Its review of events in 1989 included a detailed presentation of developments in the investigation into the death of al-Mtour and certain other deaths in detention, and with some reservations it is clear that al-Haq felt that "the consistent pressures of the past year have begun to pay off." ${ }^{2}$ Nevertheless, its conclusions were somber. Felicia Langer's petition for a new investigation into the death of al-Mtour had been rejected by the High Court "despite overwhelming evidence, disclosed by Military Police investigators," that he had been severely abused in detention. Langer concluded that "not only was justice not seen to have been done, justice was not done at all." 53 Derrick Pounder had concluded that "the cause of death was asphyxiation due to ligature pressure on the neck" and continued:

It is my opinion that more likely than not the mechanism of death was hanging. I consider that, for the three days prior to his death, the decedent was subjected to treatment which was prima facie, cruel, inhuman and degrading. I consider it possible that the decedent took his own life to escape this abuse. If such was the case, I would regard the death as an "aggravated suicide." On the information available, the possibility of homicide cannot be excluded. I consider the initial investigation of the death to have been inadequate and the information presently available to me to be incomplete. ${ }^{54}$

The increasing phenomenon of deaths in Israeli detention and al-Haq's efforts to determine cause and establish accountability had significant impact in the organization. Whether a detainee had died as result of torture or other illegal conduct or was thought to have taken his own life as a result of such treatment, the loneliness of such an end lingered in the mind, among the most compelling evidence of the lawlessness of the Israeli occupation, which was a central finding in the second year of the intifada. Al-Haq opened its report A Nation under Siege with an account of the death of Khaled al-Sheikh 'Ali, and closed it with that of Ibrahim alMtour, reproducing the organization's speech on accepting the 1989 Carter-Menil Human Rights Award:

On 18 October 1988 Ibrahim al-Mtour was seen by other detainees at the Dhahiriyya military detention centre in the West Bank. Blood was flowing from his head and he was heard screaming: "I am Ibrahim al-Mtour. They are beating me to death. Detainees, witness!"

Three days later, Ibrahim was dead. "Suicide," the prison authorities declared. It is our collective duty to answer Ibrahim's call, to witness, to act, so that in the future 
not only will the Ibrahims of this world be heard and not have to die but so that they will not have to scream at all. ${ }^{55}$

Al-Haq workers involved in following these investigations were deeply affected by the processes. Khaled Batrawi, then head of the fieldwork unit, commences a moving piece about al-Haq's work on autopsies and deaths in detention, written some two decades after Batrawi left al-Haq, with a tribute to all the martyrs of the uprising, "especially those whose skin was split by the autopsy razor. [ . . ] At the time of the autopsy, they felt no pain, but I felt pain [then] and I still feel it." ${ }^{56}$ Palestinians had, as already recognized in the Karp report, no faith in Israeli investigations (process or outcome), and had reason to fear repercussions should they seek to challenge them..$^{57}$ In addition, as Batrawi notes, it was not necessarily an avenue that Palestinian families would wish to pursue: "Palestinian society, like other Arab societies, did not accept autopsy for religious and social reasons, and the overriding concern for the family of martyrs was to bury them, given [the saying that] 'to honour the dead is to bury them [swiftly]."' And suicide was difficult to accept even where the efforts of human rights actors established "aggravated suicide" at the hands of their captors. The families of the detainees traveled a very difficult road, and their human rights contacts were bound to accompany them.

By the mid-1980s, al-Haq was also cooperating with other Palestinian human rights organizations in the occupied territories. LSM/al-Haq had actively assisted in the establishment (as an ICJ affiliate) of the Gaza Centre for Rights and Law in 1985, including copublishing a study of the military court system written by a shared researcher..$^{58}$ When the GCRL became mired in internal difficulties, the Gaza affiliate of the ICJ became and remains the Palestinian Centre for Human Rights (PCHR), established in 1995 under the directorship of lawyer Raji Sourani. Al-Haq also cooperated with the second human rights organization to be set up in the West Bank, the Palestine Human Rights Information Center (PHRIC), which operated out of Jerusalem. PHRIC was established in 1986 by the Arab Studies Society and published large amounts of data on human rights violations, particularly after the start of the intifada. In a 1988 comparison, Penny Johnson attributed "a more activist agenda" to PHRIC and less of a focus on legal research than alHaq: "Director Jan Abu Shakra emphasizes that the Center sees its primary constituency as local, because 'rights must be claimed." 59

Despite their cooperation, Rabbani has pointed to certain tensions between PHRIC and al-Haq because of the latter's sometimes perhaps overly painstaking approach and its "predictable refusal to comment on events in the Gaza Strip during 1987-1988 because it did not have its own sources of information." ${ }^{\circ 0}$ Tensions also arose with the first Israeli group to initiate systematic human rights work in the occupied territories. A new type of relationship was required when in 1989 B’Tselem was established. Rabbani's comment here is telling:

It was not unexpected that, as an Israeli organisation [ . . ] it would immediately acquire the exposure, credibility, and funding which had eluded al-Haq for 10 years. 
But when several B'Tselem staff began to conduct themselves as if it was they who had been in the field for a decade, relations began to deteriorate, reaching their low point in November 1989 when B'Tselem [ . . . ] was named as al-Haq's co-recipient of the 1989 Carter-Menil Human Rights Award for transparently political motives. ${ }^{61}$

It is surely clear that political reasons did indeed underlie the prize givers' decision to divide the honors due the ten-year-old al-Haq with an Israeli organization of one year's standing. Rabbani's piece conveys something of the rancor of that time and points to difficulties in working out peer relationships (rather than "relations of paternalism") between citizens of an occupying power and members of the occupied population. An explicit recognition of the power relationships involved, and a determination to address them, are among the requisites of such relationships as outlined in postcolonial literature. At the retreat organized in Crete in 1989 for "active and creative leaders in non-governmental human rights organisations," a question was raised as to "the degree to which NGOs within the state of an occupying power and within the occupied territory" were able to cooperate. Among the participants were Raja Shehadeh and an ACRI board member. No discussion is recorded, only the summary that "there were clear risks for both parties in such cooperation, but also strong potential benefits." ${ }^{62}$ Rabbani for his part noted a marked subsequent improvement in relations between al-Haq, B'Tselem, and PHRIC, "in an admirable show of common purpose"-given the real exigencies of the situation-and by dint of a "functional division of labour" which he described as follows:
Al-Haq's comparative advantage is in its legal knowledge, fieldwork, and its excellent contacts with the diplomatic corps and foreign elites; the PHRIC's in comprehensive documentation and reporting, rapid intervention, and an extremely professional in- ternational distribution network; and B'Tselem's-in addition to the quality of its own research-in its access to the media and official sources, and the crucial con- tribution of an Israeli Jewish certificate of authenticity to reports of Israeli human rights abuses. ${ }^{63}$

Until the intifada, al-Haq's international interventions were directed at peers in the "community of human rights organizations"; the Draft Program Objectives for 1987 observed that al-Haq had "come some way towards having them mobilise their resources in exposing and challenging human rights violations in the Occupied Territories." According to the report of the Crete retreat, "Al-Haq's primary strategy is to publicize violations through international channels, and to work with International NGOs investigating violations in the occupied territories." ${ }^{64}$ Johnson quotes Mona Rishmawi on al-Haq's concentration on information work in the international NGO community at that time and continues: "Al-Haq has pursued this route perhaps more systematically than any other organisation in the occupied territories to date. Its publications are geared to this audience." ${ }^{65}$ While both the Steiner report and Johnson's piece note al-Haq's outreach work in the local Palestinian community (especially its human rights education program), the focus 
on international allies is striking. It was, as someone from the time put it, "the first experiment where a local Palestinian organisation has a completely international law reference point and there are organisations outside backing it up; as soon as something happens you resort to your network-that's very common now but it wasn't then." It was physically also very labor-intensive work in the era before electronic communications ("countless hours sending faxes").

LSM/al-Haq's first institutional relationship was with the ICJ under the leadership of Niall MacDermot, and it benefited enormously from this relationship and different activities that developed. As did the ICJ; al-Haq was one of the most-if not the most-active of the ICJ affiliates with an international reputation of its own and eventually a size that exceeded that of its parent organization. LSM's affiliation with the ICJ was sought for a combination of motives but primarily for the possibility of protection that the founders felt might come if they established under the ICJ umbrella. Solidarity-in the form of interventions on issues within their mandates, including the harassment of LSM/al-Haq workers-was also sought from other international human rights organizations. Amnesty International was among LSM's early visitors. Al-Haq/LSM-and staffers whose cases were addressed-benefited from Amnesty's existing position in regard to membership of the PLO and the status of "prisoner of conscience." In a 1991 response to the Israeli Ministry of Justice, the organization acknowledged:

Amnesty International has a long-standing disagreement with the Israeli government over the relevance of issues such as the membership of the Palestine Liberation Organisation (PLO) in determining whether someone is a prisoner of conscience. The Israeli Government maintains that such membership of itself automatically amounts at least to advocacy of violence against Israel. Amnesty International disagrees. ${ }^{66}$

This was not a new position, nor one that Amnesty had newly adopted in response to the situation in the occupied territories. The status of prisoner of conscience, a cornerstone of Amnesty's mandate and advocacy, was reserved for those imprisoned solely on the grounds of their nonviolent expression of their political or religious beliefs. Adoption by Amnesty as a prisoner of conscience meant personal advocacy by individual Amnesty members as well as significant moral recognition. ${ }^{67}$ Amnesty's explanation to the Israeli Ministry of Justice stated that it

recognizes that the PLO remains committed to the legitimacy of the use of violent means in its opposition to Israel, that factions of the PLO have carried out acts of violence against Israelis, and that obviously a large number of PLO members approve of or sympathize with that. However, it also understands that the PLO is an organization composed of several factions and bodies involved in political, social and cultural activities as well as military or violent activities. The vast majority of Palestinians view the PLO as their sole representative and the only vehicle for organized expression of their national aspirations. Palestinians may join or be otherwise associated with the PLO because they share its overall political objectives without necessarily agreeing with all its policies, including those relating to the use of violence. 
Amnesty International does not consider that membership of or association with the PLO or one of its factions is in itself conclusive evidence that a certain individual has used or advocated violence. In determining whether an individual is a prisoner of conscience, Amnesty International looks into whether the individual personally used or advocated violence in the circumstances relating to his or her arrest. ${ }^{68}$

Amnesty applied these criteria inter alia to the status of a number of al-Haq fieldworkers arrested in the early years of the intifada. Amnesty's first substantial report on administrative detention (1989) examined their cases in some detail, as indeed did a report by the LCHR. ${ }^{69}$ A detailed exposition was made in a letter from Amnesty's secretary-general to the Israeli minister of defense in 1990 in relation to the administrative detention of Shawan Jabarin..$^{70}$ Amnesty's seven-page intervention went methodically through Jabarin's arrest and detention record, including a relatively reduced prison sentence in December 1985 because the Israeli military judge acknowledged that "relations between Shawan Jabarin and the PFLP had undoubtedly been broken at a certain stage." It raised one of the most notorious parts of Jabarin's detention history, when his lawyer won disclosure of part of the secret material on the basis of which he had been administratively detained, only for it to be revealed that the alleged incident had taken place while Jabarin was already in custody. ${ }^{71}$ The Amnesty letter also included a report of a conversation between an Amnesty researcher who visited Ketziot (Ansar 3 prison camp) with Jabarin's lawyer and very unusually managed a conversation "in private and without time limits." The letter sets out a summary of Jabarin's answers to the researcher's requests for clarification of various aspects of the Israeli allegations relating to his current administrative detention order, including stone-throwing and inciting disturbances (including during his detention). A letter from the Ministry of Justice had described Jabarin as a "hardened terrorist"; it is possibly this, as well as Jabarin's standing as a field-worker with al-Haq (and confiscation of human rights-related materials during a search of his house) that prompted the in-depth response from Amnesty to the Israeli authorities. After spending a further pageand-a-half analyzing the available evidence in regard to Israel's allegations, including the use of secret evidence, Amnesty's letter concluded that

bearing in mind the pattern of use of administrative detention by the Israeli authori-
ties and the circumstances of this case so far as information is available to us, Am-
nesty International believes that it is reasonable to conclude that Sha'wan Jabarin is
a prisoner of conscience, held on account of his non-violent political beliefs and/or
his human rights activities, and that he was unable to exercise effectively his right to
challenge his detention order.

As it happened, Amnesty's intervention was sent just three days before Jabarin was scheduled for release, but its significance is in illustrating Amnesty's application of its policy on prisoners of conscience to Palestinian detainees and the organization's questioning of the assertions by Israel's military judicial system and government of Israel's security exigencies. 
The letter also reiterated Amnesty's then position on administrative detention, outlined in the organization's 1989 report, recommending that all those held in administrative detention "on account of their non-violent political opinions or activities be immediately and unconditionally released and all others to be provided the opportunity to exercise effectively their right to challenge their detention"; and since administrative detention should not be used to avoid the safeguards of the criminal justice system, the Israeli authorities should "review the appropriateness and necessity" of maintaining the practice. Although Amnesty did not at this point work under the framework of IHL, the fact that "internment" was contemplated (albeit in extreme circumstances) by the Fourth Geneva Convention meant that the organization did not take a position on human rights grounds calling unequivocally for the end of Israel's use of administrative detention. ${ }^{72}$ The change in this position came at Amnesty's Yokohama meeting in 1991; Amnesty's International Council "decided to oppose as a matter of principle the detention of administrative detainees unless they are to be given a fair trial within a reasonable time."73 Other changes directly relating to Amnesty's work on Israel and the occupied territories were also made at the 1991 meeting, which decided that Amnesty "will oppose the forcible exile of people on account of their non-violent beliefs" and "in principle to oppose the demolition or sealing of houses as a punishment imposed for political reasons." 74 Part of the background to the changes in Amnesty's mandate was pressure from certain southern sections of Amnesty for a position shift in favor of substantive opposition to these administrative penalties. Another part of the context, however, was Amnesty staffers' discussions with al-Haq and other Palestinian human rights organizations. Claudio Cordone, then Israel / occupied territories researcher at Amnesty, recalls intensive discussion with al-Haq staffers on IHL (given Amnesty's then reliance on IHRL) and notes that "certainly work on the Occupied Territories and with al-Haq contributed to our thinking." Cordone himself began to argue whether "IHL is more or less protective of human rights" and to consider IHL more systematically over the next few years.

An issue that took longer for Amnesty to address, that was fundamental to al-Haq and other Palestinian human rights groups, and that to their minds lay at the root of Israel's other security justifications and resulting violations of civil and political rights was settlement policy and practice. Human Rights Watch took even longer. In this one can see a reflection of the disagreement reported by Steiner from the 1989 retreat, with the southern groups criticizing Westerns INGOs for too narrow a focus on individual civil and political rights and a failure to address in any depth the causes of human rights violations..$^{75}$ Peter Rosenblum recalls "great internal struggles" in the late eighties at HRW and LCHR, in particular "over the extent of their advocacy on Israel and the Occupied Territories." ${ }^{76}$ Rabbani offers several illustrations in support of his statement that "the activities of LCHR in particular have been hostage to a political agenda." 77 Neier describes HRW's work 
on Israel/Palestine as "the work that attracted by far the greatest controversy" for the organization's Middle East division, referring to "widespread denunciations" of "findings critical of Israeli government practices." In 2009 he found himself obliged to respond to a New York Times op-ed by HRW's founding chair, Robert Bernstein, criticizing HRW's coverage of Israeli violations during Israel's assault on Gaza in 2008-2009. ${ }^{78}$

Al-Haq was engaged in collaborative work with its INGO colleagues on facts and fact-finding. As Steiner's report of the discussions at the Crete retreat continued:

Gathering information is the principal occasion for cooperation between NGOs and INGOs. Local groups have greater access to the facts and can provide better documentation. But no simple division of functions exists. National NGOs do not "find the facts" which INGOs then incorporate into their reports. ${ }^{79}$

In the late 1980 os it is clear that a certain amount of tension existed around the issue. For al-Haq, it was crucial to get the information on what was going on out to international allies with wider reach in terms of public and advocacy; but there was a considerable time and effort cost, especially for field-workers, who would often accompany researchers from INGOs in their field investigations, introducing them to a range of contacts. ${ }^{80}$ The relationship differed between different organizations and indeed their different representatives; Claudio Cordone of Amnesty recalls of al-Haq in the late 1980s:

I was very impressed by the number of people involved, the quality of their thinking. It wasn't just "give me information," that was even too much, it was the discussions [... I I mean al-Haq was doing affidavits and getting the information, but it was the discussions of strategy, what do we do with them that were even more valuable.

From al-Haq's perspective, assisting research visits by international actors was a matter of methodology and principle, and of hard work. In the case of special international delegations not familiar with the context, it also represented a considerable degree of risk, beyond risks taken by the field-workers, which was sometimes not appreciated by delegation members. Foreign delegates variously fell asleep in meetings with Palestinian interlocutors, failed to pay attention, canceled meetings at short notice and for no apparent or acceptable reason, and on at least one occasion saw no problem in accepting lifts with an Israeli army jeep on a strike day when their transport could not be organized on time. ${ }^{81} \mathrm{Al}-\mathrm{Haq}$ 's international allies, it turned out, brought potential liabilities not foreseen by the organization.

Al-Haq files contain a confidential letter from Raja Shehadeh written in the late 1980 s to an international organization that had dispatched a delegation to the territories. Al-Haq was hosting the delegation and as the visit unfolded became more and more concerned at its direction and the conduct of individual members. Shehadeh's letter referred to al-Haq's "dashed hopes" and attached a detailed confidential report as a record, in the hope that this might "facilitate planning for future 
missions." The details in the report are embarrassing. For its part, the letter talks of a unilateral narrowing of the scope of the mandate-on the basis of which al-Haq had agreed to host it-by members of the mission, with the result, in al-Haq's view, that the problems encountered were not necessarily understood in their proper context; of a doubt on al-Haq's part about the desire of the mission to fulfill an investigative function, of a lack of preparedness and a lack of probing. Shehadeh concluded with an explanation of how such matters affected not only al-Haq's own credibility and reputation, but potentially the effectiveness of the delegation:

\begin{abstract}
Al-Haq's position as a Palestinian human rights organisation, arranging a programme which involved meetings with Palestinians, Israelis and the Israeli authorities was a sensitive one. The mission failed to appreciate the difficulties and jeopardised the effectiveness of their mission by inappropriate and insensitive behaviour which caused disquiet among the Palestinian community. This could have led to a refusal to cooperate with the mission on the part of Palestinians in the Territories.
\end{abstract}

Field-workers interviewed for this study stressed the effort that went into assisting and accompanying international delegations. Candy Whittome, a UK lawyer who acted as coordinator in the office for many of the international delegations or partners, remembers that "normally I was pretty annoyed with them." ${ }^{2}$ She spent considerable time reminding these visitors that it was a two-way relationship; there was "such a journey" to be traveled in the relationship between international human rights groups and their local counterparts; there was no joint planning, the field-workers were "running around and barely getting any thanks, grace was lacking." Pondering on this later, she reflects:

I'm not sure I was brave enough to use the word at the time but exploitation is the word that springs to mind. I felt very strongly that people came with models of how things should be and they were simply thinking about it in their terms, we need this information you've got, then we-the great, the good, the powerful-we can publish it and then we'll make everything all right for you [ . . . ] Obviously I'm exaggerating the point, but there was a strong feeling that this was not a partnership or a collaboration, it was "we need this from you, we need the information, where is it?" Obviously some were better than others and you saw that quite clearly. ${ }^{83}$

Whittome stresses the importance of these episodes in building the relationship and getting out al-Haq's information, and reports productive discussions when the human costs and complexities of al-Haq's contribution to their visit were explained to members of different delegations. Increasing confidence and improvements in communications technology have changed much. For one thing, as Donatella Rovera of Amnesty International says, the local-international NGO dynamic has changed: "The days are gone when international NGOs would squeeze local ones for their data-now the local NGOs can publish it themselves, why should they give it to internationals?" In some cases, international organizations now publish joint reports with local ones. Palestinian (and indeed other 
Arab) human rights groups expect peer relationships with their international counterparts, particularly given increasing recognition of the formers' foundational role in the global movement.

\section{THE ICRC}

One of the most significant disagreements that al-Haq had with an international partner was with the ICRC. ICRC delegates arrived in Israel a few days before the 1967 war, alerted by growing tensions in the region to the likelihood of a need for its presence. ${ }^{84}$ The 1967 war was a turning point for the working methods of the ICRC, with a "fundamental shift in the behaviour of the institution as it now anticipated its possible interventions." ${ }^{35}$ Another distinguishing feature is pointed out by Moorehead, writing in 1998 that, despite fluctuations in the number of delegates and offices over the years, "it [Israel] is the only country which the Committee has never judged sufficiently peaceable to enable it to withdraw all its delegates." 86 A posting in Tel Aviv or Jerusalem was a formative experience for ICRC personnel. ${ }^{87}$ The many complex contextual issues include the ICRC's notoriously dismal record in regard to Jewish and other victims of Nazi Germany in the Second World War, when the ICRC by all accounts (including subsequently its own) "lost its normative compass." ${ }^{88}$ Moorehead's history of the ICRC invokes a "famous meeting" when it was agreed that "it was not in the best interests of the International Committee or of the victims of war they had been set up to protect to speak out about the concentration camps." 89 This goes most immediately to the ICRC's deployment of its confidentiality policy and the decisions it takes on when to speak out. In regard to ICRC delegates in Israel, Moorehead says, "in no other country does the Committee's war time past surface so relentlessly." ${ }^{\circ}$

The Swiss organization's status and mandate is distinct from human rights NGOs, lawyers' groups, and other international allies. It is a humanitarian agency specifically focused on IHL, the "guardian" of the Geneva Conventions. ICRC delegates-in LSM's early days a role restricted to Swiss nationals-were in regular contact and dialogue with LSM from the start. Under the Fourth Geneva Convention, the occupying power is obliged to request or accept "the offer of the services of a humanitarian organisation, such as the International Committee of the Red Cross, to assume the humanitarian functions performed by Protecting Powers" ${ }^{11}$ should the system of protecting powers fail and the protected population of the occupied territories be left without a neutral state to act as representative of all the state parties to the convention in safeguarding their rights and interests as protected under the convention. Early in the occupation, and "in spite of the ICRC's persistent representations," the Israeli government "declared that it wished 'to leave in abeyance for the time being' the question of the applicability of the Fourth Convention in the occupied territories, preferring to act on a pragmatic basis by granting delegates practical facilities." ${ }^{92}$ Holding that the convention applied de jure, in 
1972 ICRC made a formal offer to act as an official substitute for the protecting power, which Israel declined; by now unequivocally holding that the convention did not apply as a matter of law, the Israeli authorities claimed that they would abide by its "humanitarian provisions" but not its "political provisions"-a distinction not recognized in the convention itself, nor by the ICRC and state parties. ${ }^{93}$

This was the position advanced by Haim Cohn in his introduction to the Israeli ICJ's response to LSM's The West Bank and the Rule of Law. In 1977, the ICRC had made a public statement to the effect that a number of problems it had been raising regularly with the Israeli authorities remained unresolved, and they were still not allowed to see detainees under interrogation. ${ }^{94}$ Negotiations continued, and in 1978 the ICRC and the Israeli Government concluded a formal agreement to govern the ICRC's action in the occupied territories. ${ }^{95}$ The Israeli government undertook to inform the ICRC twelve days after any arrest of Palestinians from the occupied territories and to grant delegates access to the detainee within fourteen days of the arrest; during a visit, the ICRC delegate could speak to the detainee "only about his personal situation and the state of his health" and was "prohibited from transmitting any information whatsoever to an outside body or to the family of the detainee other than the date of arrest, the place and date of visit and the detainee's state of health." ${ }^{96}$

As Shehadeh acknowledged, the argument in support of this arrangement was that such visits were better than no visits at all. ${ }^{97}$ When mass arrests began in the first intifada, al-Haq itself was only able to find out the whereabouts of some of its detained field-workers through the ICRC. However, frustration was growing with the limits-both contractual and self-imposed-of the ICRC's activities in the occupied territories. Shehadeh noted that the fourteen days before ICRC visits provided the military authorities with ample time to isolate and interrogate and mistreat detainees, and that "in the opinion of many ex-prisoners, the visits of the ICRC were of little, if any, significance or practical help." ${ }^{8}$ With its work on alFara' prison in the forefront, al-Haq was beginning to feel like a voice in the wilderness, as one interviewee recalled, and clearly they felt that the ICRC should be speaking out. A 1985 Newsletter set out concerns about the use made by the Israeli authorities of the fact that the ICRC did not (could not) share its information or its reports with "anyone other than the Israeli authorities"; this was in relation to LSM/al-Haq's investigation of complaints against Israeli medical personnel, described above. Al-Haq noted, "It is the Israeli authorities' practice to refer to the Red Cross visits whenever allegations are made about prison conditions, as though the silence of the Red Cross disproves the allegations."99

Al-Haq was becoming frustrated with the confidentiality policy of the ICRCnot a policy specific to the occupied territories-and its reluctance to go public even with broader concerns that would not violate its agreement with the Israeli authorities. In its second report in the uprising, al-Haq noted the ICRC's public 
statements on the Iran-Iraq war in 1983-84 in regard to the duty of all state parties to ensure respect for the Geneva Conventions:

It is therefore surprising, although irrelevant from a legal point of view, that the ICRC has made no such public appeal to state signatories in response to Israel's 22-year-old occupation of the West Bank and Gaza Strip. The danger clearly inherent in such a policy is that the ICRC's silence may be interpreted as tacit approval of Israel's policy. In such an event the continued presence of the ICRC might become counterproductive. ${ }^{100}$

Al-Haq's relations with the ICRC were becoming fraught. As the first intifada wore on, the ICRC did make a number of public statements about Israel's treatment of Palestinian detainees, stating in 1992, for example, that through private interviews with those under interrogation "it has reached the conclusion that to obtain information and confessions from detainees, means of physical and psychological pressure are being used" in violation of the Fourth Geneva Convention and that ICRC representations to the Israeli authorities had had no effect. ${ }^{101}$ It might have been this public intervention that was the cause of a return to "icy formality, and a very literal interpretation of our mandate" by the Israeli authorities, described by a former ICRC delegate. ${ }^{102}$ On the practical level, the ICRC's medical, health, and other services to the West Bank and Gaza increased in range and in focus as the occupation dragged on. ${ }^{103}$

It is now clear that a further distinguishing feature of the ICRC's relationship with Israel and the occupied territories arose directly from Israel's sustained refusal to acknowledge the de jure applicability of the Fourth Geneva Convention and its equally persistent structural violations manifested most obviously in settlement policy. At the start of 2012, an interview with Raja Shehadeh was published in the International Review of the Red Cross as part of a special thematic edition on occupation. Selected for interview as "someone who has lived and practised law in an occupied territory," ${ }^{104}$ Shehadeh was asked what his expectations had been of the ICRC. Shehadeh first paid tribute to the "help given on a small scale" to detainees otherwise in isolation, which was "not to be underrated." However, looking back, he observed, "Maybe my expectations were simply too high. [ . . . ] Maybe that's always a problem when you start out with high hopes - the hopes are dashed." He then went on to regret what he had perceived as

reluctance on the part of the ICRC to take up issues in an effective way, to speak out openly against the settlements or the civil administration, and to use every possible power the organization has to help put a stop to these detrimental violations. Sometimes I detected more fear of speaking out against Israel than I had witnessed in Israel itself.

He had himself challenged ICRC delegates on many occasions. He agreed with the importance of "being economical in the frequency of public statements"-after all, 
this had also been the practice at al-Haq. However, he was of the opinion that "the ICRC did not speak out when it should have."

The same volume of the Review, published on the 15oth anniversary of the founding of the ICRC, included a paper by the then ICRC president, Peter Maurer, on "Israel's occupation policy," presented as a decision by the ICRC "to engage in a public debate over these issues." ${ }^{105}$ Maurer tells his readers that "the particular challenges of humanitarian action" in Israel and the occupied territories cannot be tackled without "an honest look at certain Israeli policies that have become key features of the occupation." ${ }^{106}$

The ICRC has been unable to engage in any meaningful dialogue with the Israeli government on the impact for Palestinians of Israel's annexation of East Jerusalem, the routing of the West Bank Barrier, and the presence and further expansion of Israeli settlements. The ICRC has therefore opted to engage with civil society, academia, and the Israeli public directly in explaining its position regarding the discrepancies between IHL and the Israeli Government's policy in the Occupied Palestinian Territory. ${ }^{107}$

If this initiative was a departure for the ICRC in method, it was not a change in position. The ICRC had, in previous public communications over the years, made clear its position on the IHL rules governing Israel's occupation of the Palestinian territories (including East Jerusalem). ${ }^{108}$ Introducing the reader to the 150 th anniversary issue of the Review, the editor-in-chief stated that "over the years the ICRC has chosen to develop direct and confidential dialogue as its privileged method of engagement with its interlocutors" - this approach was "at the core of its identity." ${ }^{109}$ At stake was access to those the ICRC was committed to assisting, which meant building and maintaining the trust and confidence of its interlocutors. Bernard insisted on the effectiveness of the confidentiality approach "from the humanitarian point of view" while stressing that it was not unconditional, that progress must be made, and that the quality of the dialogue was important.

As part of engaging in public debate, the Review solicited and published a response to Maurer's piece by Alan Baker, who had served as legal adviser to the Israeli Ministry of Foreign Affairs and as a military legal adviser in the Israeli army, among other positions. ${ }^{110}$ It is hard to read into Baker's response any positive movement towards the ICRC's suggestion of a public debate and dialogue. Baker repeated the official Israeli positions on all the issues of law and policy raised by Maurer as core concerns for the ICRC, repeating the standard assertion that in any case the convention did not apply. ${ }^{111} \mathrm{He}$ did not take up the issue of the confidentiality dilemma posed by Maurer for discussion, but rather took the ICRC to task on another of its core principles, the "fundamental principle of neutrality." Baker tackled Maurer for his use of the designation "occupied Palestinian territory," which Baker rejected as "inaccurate historically and legally, and [ . . ] inherently and clearly politically slanted." ${ }_{12}$ Turning at the end to the ICRC's idea of a public debate on Israel's occupation policies, Baker told the ICRC president: 
Engaging the public, whether through public speeches and statements, the public use of politically-generated terminology, reliance on biased and inaccurate information, and the adoption of formal policy positions based in political assumptions that have the potential to influence, undermine or prejudice ongoing processes of negotiation and reconciliation, would all appear to run contrary to the fundamental principle of neutrality. ${ }^{113}$

For Baker, insisting on IHL principles risked disrupting rather than underpinning political negotiations. These arguments are similar to those that blocked development of law-based political positions by European states in deference to a US political agenda following the first intifada.

\title{
THE ENFORCEMENT PROJECT
}

Notwithstanding al-Haq's criticism of the ICRC in the 1980s, a dialogue had been opened up with delegates in Jerusalem and through them with officials in the Geneva-based Department of Principles, Law and Relations with the Movement. From al-Haq's side, this effort was led by Charles Shammas and focused on the rights and duties of Israel's coparties to the Fourth Geneva Convention in affording protection to the Palestinian population. Al-Haq Draft Program Objectives for 1987 noted that it was

\begin{abstract}
imperative for al-Haq to seek to activate alternative mechanisms of enforcement and accountability within the international community of law. Towards this end, al-Haq plans to address governmental and non-governmental members of the system who proclaim adherence to the body of human rights and humanitarian law with the intention of enforcing on them their obligation to investigate and intervene against violations, and to participate in enforcement. ${ }^{114}$
\end{abstract}

The first direct "Appeal to State Signatories to the IV Geneva Convention" was issued as a press release (its tenth ever) by al-Haq five days into the first intifada, calling on states "to intervene urgently with the Israeli authorities to halt the killing and wounding of Palestinians in the occupied West Bank and Gaza." ${ }^{115}$ Describing its repeated interventions with the Israeli authorities over the previous three years regarding instances of death and wounding caused by the use of live ammunition, and noting the authorities' "tacit approval of the 'shoot-to-kill' practices of the military," the organization explained:
Al-Haq is calling upon the state signatories to the Fourth Geneva Convention to car- ry out their legal and moral obligations under the Convention. Under Article 1 of the Convention, signatory countries have undertaken not only to respect the Convention themselves, but also to ensure respect for the Convention. The underlying principle on which the Convention rests, namely respect for human life, is being violated. ${ }^{116}$

The next month, as the European Parliament was considering the ratification of new trade protocols with Israel, the Israeli authorities issued nine deportation 
orders as their violent reaction to the intifada continued. A memorandum by alHaq explained the organization's standing to make a direct claim on state parties to the Fourth Geneva Convention:

\begin{abstract}
Al-Haq has addressed the enclosed memorandum to the European Community, its President, Parliament and member states, in its capacity as part of the protected population recognised by the Convention, and on behalf of that population. We present it as a Palestinian petitioner with standing under the Convention, with a right to claim the protection of the Member States and of the European Community. In so doing, we affirm our obligation to help activate the body of humanitarian law, the respect for which we believe unites us. ${ }^{17}$
\end{abstract}

The memorandum reminded state parties of their "duty under Article 1 to 'ensure respect' by third parties" and argued:

To renew preferential trading privileges in the face of Israel's continuing serious violations of the Fourth Geneva Convention, and in the face of Israel's proclaimed intent to persist in committing such violations, would be an act of acquiescence to Israeli lawlessness. ${ }^{118}$

It followed that, before ratification of the EEC trade agreement with Israel, states should request, "as a condition precedent, an undertaking by Israel to comply with its obligations under the Fourth Geneva Convention." It was a departure for alHaq to directly address elected parliamentarians in this manner. In the autumn of 1988, the Enforcement Project was formally established with the recruitment of a full-time worker (myself), based in London and going between Europe and Ramallah, and the participation of staffers in Ramallah. The end of 1988 saw alHaq publish its first annual report, a development driven entirely by the continuing escalation of the intifada and Israel's reactions to it, rather than by forward planning. The conclusion invokes Article 1 of the Fourth Geneva Convention as a basis for "active international intervention to safeguard the lives and rights of the Palestinians as protected persons." ${ }^{119}$ Its more planned-for successor, A Nation under Siege, gave sustained attention to the arguments being developed by the enforcement team.

During 1989, the second year of the intifada, al-Haq delivered interventions to governments through their consulates in East Jerusalem, calling for in situ monitoring and intervention by consular officials and the conduct of consular investigations, notably after a massive raid and multiple casualties in the West Bank village of Nahhalin and after "tax raids" in Beit Sahour. ${ }^{120}$ The first of these protested "the failure of State Signatories to the Fourth Geneva Convention to provide any effective measure of international protection to the Palestinian population of the Occupied Territories" and appears to have been the first intervention in which al-Haq specifically drew attention to the category of grave breaches of the convention. The second urged consuls (in the absence of a protecting power) to "visit Beit Sahour and intervene with the Israeli military and tax authorities there, 
in order to provide a measure of physical protection for the inhabitants of the town in line with your duties under Article 1 of the Fourth Geneva Convention 1949." Consuls-general of seven European states set out on a fact-finding visit, only to be turned back at a roadblock by an Israeli officer who stated that the town had been closed "for operational reasons." ${ }^{121}$ The British consul-general also visited Nablus and called for an investigation into a killing by the Israeli army. ${ }^{122}$ Following a formal complaint made against the British consul-general by the Israeli ambassador in London, a parliamentary question prompted a Foreign Office minister to confirm that the consul-general had "done nothing without instructions from the British Government" and "nothing outside his proper role." 123

In the meantime, the Enforcement Project was also developing its Europefocused advocacy and allies. In the summer the first of four "enforcement symposia" was held, each with the participation of legal and political actors. These were the result of steady efforts in making contacts, presenting arguments, drafting parliamentary questions, sending letters to ministers, and other interventions. Other advocacy groups use similar methods, but al-Haq's efforts were distinguished at the time by its focus on IHL and third-party states' law-based rights and responsibilities. Besides setting out to a wider audience al-Haq's thinking on the law-based role of third parties, the symposia provided related opportunities; in London in 1989, for example, to draw out the ICRC. In response to a letter sent to its president by the two British MPs convening the enforcement symposium, the director of the ICRC's Principles, Law and Relations with the Movement Department wrote back confirming that:

The ICRC considers it vital that the States party to the Geneva Conventions take all possible steps to ensure respect for that body of law, the purpose of which is to lessen the suffering of people affected by armed conflict. It is moreover a legal obligation for them to do so because, in becoming party to the Geneva Conventions, those States have undertaken not only to respect the said Conventions themselves, but also to ensure respect for them by other States in all circumstances. This is the tenor of Article 1 common to the four Conventions. ${ }^{124}$

The ICRC response had taken a while to be drafted (the MPs' letter was sent over three months before), but it arrived in time to be included in the publication arising from the symposium. ${ }^{25}$ Back in Ramallah, al-Haq was preparing its second annual report, A Nation under Siege, which was to show the impact of the developing enforcement thinking. A chapter titled "The Role of the International Community" set out how different law-based options and roles came together in this context, and the report's exposition of violations committed over the course of the year identified those constituting "grave breaches" of the Fourth Geneva Convention. As a category of violations, grave breaches are the only instance where other state parties are required to take specific action, promulgating legislation allowing them to prosecute those against whom there is relevant evidence wherever the violation occurred. ${ }^{126}$ In Ramallah, fieldwork coordinator Khaled Batrawi opened 
"grave breaches" files in an early attempt to collect documentation for use in criminal cases against alleged perpetrators, albeit the organization's understanding of evidential and other requirements was, at that time, rudimentary. ${ }^{127}$

The Enforcement Project was thus from the start distinguished from al-Haq's treatment of the law, and documentation of violations, by its focus on how to get third states acting in support of the law. ${ }^{128}$ The exigencies of the intifada and the Israeli authorities' response thereto gave enormous impetus to the work and secured an audience for the arguments. As Shammas has put it, "largely untutored in the workings of international law, the Project's approach was based on logical necessity: we needed the law to work, and logically it had to work: we had to work out how." ${ }^{129}$ With the ICRC, he recalls, "we [the Project] were recognised as a kind of very operational provocateur in terms of questions of doctrine." In 1990, Shammas was invited as a panelist-along with members of the international legal community - at the Fifteenth Roundtable of the International Institute of Humanitarian Law in San Remo, an annual event convened by the ICRC and other nongovernmental and intergovernmental actors, to contribute to the discussion on Article 1's requirement of state parties to "ensure respect for" the convention. The summary of proceedings reports that the majority in the working group took the view that "although the majority of the participants in the Diplomatic Conference of 1949 [which adopted the texts of the Conventions] did not intend the phrase 'ensure respect for' to engage the responsibility of third States, it had now become clear that Article 1 created both a right and an obligation for third States to ensure respect for IHL." ${ }^{130}$

The ICRC's interpretation is not accepted by all IHL scholars and experts, but it is a measure of the reach of this advocacy that those who disagreed nevertheless paid attention to the arguments made by al-Haq and its allies. Prominent Dutch jurist Frits Kalshoven explained as follows the arguments of those he referred to as "the Palestinians and their supporters":

Their argument: by virtue of common Article 1, all states, and particularly those with close relations with Israel, are under an obligation to ensure that Israel respects all the rules of the Fourth Convention relative to military occupation. In support of their contention, they rely squarely on the ICRC Commentaries to the Conventions. Their interest was, and is, of course, to see that Israel remains under constant international pressure to relinquish the territory it keeps occupied. Given that interest, they may be forgiven for accepting the ICRC stance as gospel truth. ${ }^{131}$

That same year, 1990, also saw significant action by regional and intergovernmental bodies in regard to the application of IHL to the occupied territories-and, critically, the role of third-party states. The context included key events in the ongoing intifada as well as developments in Israel and internationally. The then Soviet Union was exercised about reports that large numbers of Jewish Soviet citizens emigrating to Israel under recently agreed arrangements were being settled 
in the occupied territories, including East Jerusalem, and sought to have the issue of settlements addressed in the Security Council. The United States, while generally avoiding asserting its previous position of the illegality of Israel's settlement policy in favor of insisting that settlements were an obstacle to peace, held up a significant US loan guarantee to Israel for the housing of Soviet immigrants when Israel declined to give assurance that the funds would not be used directly or indirectly to support settlement activity in the occupied territories and particularly East Jerusalem. In the meantime, the killing of seven Palestinian workers inside Israel in May and the killing of fifteen and wounding of some two thousand others during ensuing protests in the occupied territories prompted the drafting of what became known as the "protection resolution" at the UN Security Council. This envisaged a Security Council Commission being dispatched to recommend "ways and means for ensuring the safety and protection of the Palestinian civilians under Israeli occupation." At the end of May, the United States vetoed the draft resolution, but the issue returned in October, particularly after mass killings and injuries at al-Haram al-Sharif in East Jerusalem. With Israel still refusing to receive a team from the UN secretary-general, a report was written without a visit, giving specific focus to the obligations of Israel and also of third-party states under the Fourth Geneva Convention. Negotiations began at the Security Council on the text of a resolution.

These negotiations were still in progress when in December Israel announced deportation orders against four Palestinians from Gaza. The UNSC adopted Resolution 681 (1990), which called upon state parties to the Fourth Geneva Convention "to ensure respect by Israel of its obligations in accordance with Article 1." Dormann and Serralvo give this resolution as an example of states actively seeking to prevent violations of IHL in furtherance of their duty under Article 1 "to ensure respect" for the convention, acting as they did on Israel's announcement of its intent to commit the violations. ${ }^{132}$ These developments were analyzed by al-Haq in its third annual report, Protection Denied. Al-Haq described the adoption of Resolution 681 as "a milestone." It was the first time the organization had reviewed UN developments in this way. ${ }^{133}$ Elsewhere in the region, in August Iraq invaded Kuwait, and in January 1991 US-led forces engaged Iraqi troops in Kuwait in Operation Desert Storm. The aftermath of this included fresh efforts by the US administration to broker Israeli-Palestinian talks that were to lead to the Madrid talks later in 1991. In Protection Denied, al-Haq inter alia drew attention to the fact that the Security Council had been quick to explicitly allege grave breaches of the Geneva Convention by Iraq during its occupation of Kuwait, while remaining unable to agree on a text that would refer to Israel's policy-based grave breaches in the occupied territories. ${ }^{134}$

In June 1990, after the United States had vetoed the draft "protection resolution" at the Security Council, al-Haq and the PHRIC in Jerusalem issued a statement titled "Representation to State Signatories of the Fourth Geneva Convention" 
that addressed a set of possible measures to be taken, firstly through the United Nations and secondly by individual states. The accompanying supplement was titled "The Need for International Protection." ${ }^{35}$ This representation is the most indicative statement of the thinking of al-Haq on enforcement in the circumstances of that period. It began with the possibility for protection to be afforded by the action of third-party states through the United Nations in accordance with the Uniting for Peace Resolution (1950) and the stationing of an observer force in the occupied territories. In the end, it was not until 1997 that the UN General Assembly employed the Uniting for Peace mechanism to establish the Tenth Emergency Session (on "illegal Israeli actions in occupied East Jerusalem and the rest of the occupied Palestinian territory"). ${ }^{136}$ This forum reconvened over the years and gave rise to three conferences of High Contracting Parties on "measures to enforce the Fourth Geneva Convention in the Occupied Palestinian Territories" (in 1999, after further vetoing by the United States at the UN; in 2001 after Ariel Sharon's visit to al-Haram al-Sharif and the eruption of the second intifada; and in 2014, after Israel's summer assault on Gaza). These conferences produced no discussions on mechanisms to operationalize the law. ${ }^{137}$ The introduction of "refugee protection officers" by the United Nations Relief and Works Agency (UNRWA), following Security Council Resolution 681 (1990), was to prove important in many individual cases, although the public reporting mechanism quickly ceased to operate. The other observation/monitoring mechanism instituted by international actors in the occupied territories, the Temporary International Presence in Hebron (TIPH), was established after the massacre at the Ibrahimi mosque by Israeli settler Baruch Goldstein at the end of 1994. The TIPH was created outside the framework of IHL and given no public reporting mandate or authority to intervene; it remained in the city of Hebron until expelled by Israeli prime minister Netanyahu at the end of January 2019. ${ }^{138}$

As for action by states "jointly and severally," the 1990 representation suggested how states might instruct their consular officials and asked states to confirm that monitoring Israel's compliance with the convention was a principal duty of these officials and in their own national interest, given their obligations under Article 1. The eliciting of statements from "like-minded states" - which would acknowledge a common interest in upholding the norms and protections of IHL-was an initial focus of the Enforcement Project, supported by its advocacy efforts in the countries and institutions of the then EEC. The reaction of PLO representatives and officials in different European countries at the time was varied, sometimes supportive and excited, mostly rather disinterested; direct contact at the time would have posed a risk to al-Haq, but the arguments were presented through intermediaries.

The circumstances of the time allowed a measure of success to these efforts. At the end of June 1990, the Dublin Declaration, issued by the European Council at the end of the Irish presidency, included an unprecedented reference to the obligation of parties to the Fourth Geneva Convention to respect and ensure respect 
for the convention in the occupied territories. ${ }^{139}$ In December the adoption of UN Security Council Resolution 681 (1990) also provided space for efforts to encourage "like-minded states" to consider ways of operationalizing the law through efforts to act in cooperation (in accordance with United Nations principles) in defense of the law. The secretary-general was asked to solicit the opinions of member states on ways and means to ensure the safety and protection of the Palestinian population, specifically seeking their input on the idea of convening a meeting of the High Contracting Parties to the Fourth Geneva Convention. In May 1991, a common response from the then twelve member states of the European Community supported the idea of a meeting at a "favourable time." In the meantime, they would be considering the establishment of a "consultative committee" which could seek ways of ensuring respect for the convention in the occupied territories.

The final part of al-Haq's 1990 representation to the signatory states concerned the duties of third-party states in regard to grave breaches of the convention by the occupying power. The exercise of universal jurisdiction over grave breaches had been an early focus for the Enforcement Project, being the only measure of enforcement that state parties to the convention are under an obligation to take. At the time, there was considerably less interest, knowledge, and activity around the issue of universal criminal jurisdiction than is the case now; the International Criminal Court was nearly a decade away. The only available criminal court recourse, failing that of the occupying power, remained the national courts of third state parties, which had no history of being put to such use. The initial research and contacts made by al-Haq's Enforcement Project, although valuable, could not take such hugely complicated efforts forward. It was not until many years later that moves towards prosecutions in third states for grave breaches began in earnest. ${ }^{140}$

In 1990, the scale of violations taking place during the intifada and the quite desperate situation of the civilian Palestinian population, combined with a growing international perception of Israel's intransigence and a relatively facilitative international climate, had made it possible to secure some developments towards a law-based approach, in particular on the part of EU states and their diplomatic personnel. This was short-lived. As of the spring of 1991, against the background of the first Iraq war, these developments and initiatives were shelved in deference to the US-led political initiative in the region. The Madrid talks, the Oslo processes, and the establishment of the Palestinian Authority transformed the context yet again. ${ }^{141}$ Hajjar notes in relation to the political process that "the biggest blow for the human rights movement was the direction the negotiations took, namely the emphasis on security and territory rather than rights." ${ }_{142}$ The United States began to consider IHL as an unacceptably tight constraint on its political interventions, and European states had no political will to challenge the US on this. From being the law that was designed to facilitate an end to conflict, IHL came to be viewed, by powerful third parties, as itself an obstacle to peace. ${ }^{143}$ 
By the time of the 1993 Declaration of Principles, the institutional home of the Enforcement Project had moved away from al-Haq and was now hosted next door in the office of MATTIN as the ambitiously named Centre for International Human Rights Enforcement (CIHRE). By the late 1990s, the work had developed into MATTIN's core program, and Shammas and his colleagues worked with European and Palestinian allies (as well as advising Palestinian officials) in an increasingly technocratic focus on "passive enforcement" in sustained engagement with European Union states and bodies. ${ }^{144}$ The articulation of the established state duty of nonrecognition as the legal obligation incurred in the Article 1 text "to ensure respect" was a key development that has also been taken up by other Palestinian human rights organizations and allied advocacy. Shammas has termed this approach noncontentious, while noting that "more unusual was its application, in technical detail, to areas of state practice such as community law, rules of origin and other texts of trade agreements." ${ }^{145}$ In 2013, Shammas's sustained work with MATTIN colleagues on the responsibility of EU member states in this regard was credited in an al-Haq position paper in further illustration, perhaps, of how work once regarded as controversial in the human rights field has been mainstreamed. ${ }^{146}$ In the summer of 2013, in a major breakthrough, the European Commission issued a notice implementing a previous position that "all agreements between the State of Israel and the EU must unequivocally and explicitly indicate their inapplicability to the territories occupied by Israel in 1967." ${ }^{147} \mathrm{Al}-\mathrm{Haq}$ posted on its website a notice welcoming this development in the name of the Palestinian Human Rights Organisations Council (PHROC), with the logos of eleven council members attached. ${ }^{148}$ In a further breakthrough, in 2015 the Commission gave "interpretive notice" on the identification of the origins of goods from the "territories occupied by Israel since June 1967"-as PHROC hailed it, "EU labelling of settlement products" to ensure they do not enter EU markets as "produce of / made in Israel."

However, at al-Haq in the early nineties, the Enforcement Project was increasingly being seen as problematic. As the work took a higher profile both locally and internationally, a number of doctrinal and political challenges were posed. Perhaps the most significant was-and is-whether there is a conflict, or contradiction, between working to achieve the implementation of IHL in the occupied territories and working to achieve an end to the Israeli occupation. This objection was made by local and international interlocutors at the beginning of al-Haq's Enforcement Project; and it has been, and continues to be, voiced explicitly by individuals with an interest in the law, including legal practitioners and academics, as well as by actors engaged in the broader political debates and-implicitly-by those tired of the rhetoric of international law in the face of its manifest failure to protect.

Against the background of massive violations of IHL during the first intifada and unprecedented media coverage of the same, this anxiety reflected concerns that for external actors to oblige Israel into an attitude of compliance with its 
obligations as an occupying power would be to return to the previous image of Israel as a benign occupier. If Israel were obliged to correct its conduct, would the international attention given to addressing the situation, prompted and fueled by the ferocity and visibility of ongoing violations of IHL, be reduced and the political impetus to bring Israel into negotiations about ending the occupation falter?

Al-Haq's Enforcement Project-and its successors-argued that the logic of the law is otherwise. ${ }^{149} \mathrm{IHL}$ does not "preserve" a situation of occupation, but does regulate it. It should serve as a holding mechanism for the status of the occupied territories and the rights of the population, but also facilitate ending the occupation. Fundamentally, the law establishes protections for an occupied population and prohibits the occupying power from pursuing an annexationist agenda. Properly implemented, the law protects the prospects for political settlement from being derailed by the rancor caused by serious human rights abuses, and from impasses created by policies of conquest and annexation, in pursuit of which abuses are committed. By rendering such policies and their results illegal in and of themselves, the law is supposed to remove potentially intractable obstacles from the negotiating process, and to offer the occupying power, prohibited from acquiring any significant advantage from the land or resources, little prospect of gain in prolonging its occupation. Conversely, reluctance by powerful third parties to act in defense of the law when challenged by the occupying power can undermine both the will to negotiate and support for those charged with negotiating. In the case of Israel, after years of failure to ensure Israel's compliance with IHL, its violations of international law became the basis upon which negotiations, once started, were premised. Failure to respect or ensure respect for the law thus had (and continues to have) tangible consequences for both human rights protection and dispute resolution. In the case of the occupied territories, de facto toleration of its nonimplementation has led to the "creation of facts" in violation of the conventionmost notably settlements and the annexation of East Jerusalem-that continue to constitute some of the most difficult and apparently intractable issues on the negotiating agenda, such as it is.

Doubts about the political utility of seeking law-based conduct by the occupying power had been posed to al-Haq's founders and field-workers since the establishment of the organization. Nevertheless, Rabbani's 1994 understanding of the Enforcement Project was that it occasioned a "gradual politicization" in al-Haq, whether through those whom the project was engaging ("politicians as a primary audience") or the associated "necessity to develop appealing political arguments" 150 - what might be described as utilitarian arguments linking law-based action with political goals desirable to European political interlocutors. Some alHaqqers apparently worried that the enforcement approach might undermine the political battle to end the occupation and realize the right to self-determination.

This argument became pertinent again alongside internal developments. The talks in Madrid and Washington began to bring out political differences among 
al-Haq staffers that were not easily submerged by the considerable ongoing workload. The Madrid talks of 1991 also provided the immediate cause for Raja Shehadeh's decision to leave al-Haq's board when invited to join the Palestinian delegation to Madrid and then the United States as a legal adviser. Jonathan Kuttab left at the same time-he and Shehadeh, as well as Shammas to a certain extent, had wearied of the heavy responsibilities and the increasing wrangling among al-Haq staffers. And all had other professional engagements to which they wished to devote more time than their al-Haq duties permitted. Staff-board differences included remaining anger on the part of some staffers over Mona Rishmawi's departure and at the departure of two members of the founding board, as well as the eventual failure to forge a working relationship with the new board. The Enforcement Project was probably as much a victim of these turbulent developments as of its own weaknesses.

Among al-Haq workers, there were other reservations about the project. Interviewed for this study, staffers from the time recalled finding the Enforcement Project-variously—new, unclear, badly communicated, "parachuted in," highly complex, esoteric, the "fourth generation of human rights work," "a very strange project for us," and scary- "we weren't sure where was it taking us." 151 Khaled Batrawi, an enthusiastic member of the Enforcement Team, says that the work was "not among the known alphabets" of human rights work at the time. ${ }^{152}$ Internally, it was al-Haq's most controversial project. A number of factors appear to have combined to generate discomfort, starting with the direct engagement with elements of foreign political systems. Seeking action from powerful third-party states to correct conduct by the occupying power did not hold the same costs for Palestinians in the occupied territories as it would for those working in national systems with sovereign governments; nevertheless, for rather different reasons, some at alHaq felt that talking to governments was the prerogative of the PLO, as the Palestinians' political representative. Here, even with Jerusalem-based consuls-general, Mona Rishmawi recalls that "it was a big political issue when we started talking to them." The ideas and the work developed apace, and Charles Shammas was not at his best in explaining them to the rapidly increasing numbers of staffers assembled at the general meeting. Despite the building of an Enforcement Team at al-Haq that drew on members from different units, the project was seen as "particular to Charles" (whose role at MATTIN was also not always understood) and otherwise dependent on non-Palestinian staff. Despite its impact on the substance of the second and third annual reports and in interventions, the project did not manage to integrate its work into the organization as a whole; it was always somehow isolated. Neither Shehadeh nor Kuttab was engaged with the project, and some had doubts that these two were really in support but also felt unable to tell Shammas of their concerns. It was expensive, with the UK field representative based in London and high travel costs for the advocacy schedule in Europe. European donors were particularly enthusiastic about the project and earmarked funds for its support at al-Haq; ${ }^{153}$ but there was a perception of foreign travel, privilege, and prestige 
associated with the project that, together with this high level of funding, generated questions and risked resentment. Even the project's then innovative use of email for communications gave rise to comment, whether for using dial-up modems that tied up al-Haq's phone line, which was needed for the field-workers to call in, or because it was one more thing not familiar (and not adequately explained) to fellow workers. It was also in the nature of the work that the European advocacy and research side suffered from a lack of direct or daily oversight from the al-Haq office in Ramallah, although the project was also accused of "overreporting" on its activities, taking too much of staffers' time to explain itself and-from a management perspective-filling up filing cabinet drawers with lengthy reporting documents that nobody had time to read.

Finally, the board that succeeded Shehadeh, Kuttab, and Shammas felt there was risk of a conflict of interest. Charles Shammas had himself stayed on the new board with a view to providing some institutional memory and aiding the transition to the new governing body. He did not see a conflict of interest through his holding an (unpaid) operational role in the organization's work, although he offered to withdraw. Discussions with members of the new board became increasingly acrimonious, however, and in June 1992 the board decided to terminate the project by the end of the year. The reasons given were "the high financial cost of the project" and "the administrative complications arising mainly from Charles' double role as a board member and project coordinator. [ ... ] We are sorry," wrote al-Haq's then program coordinator to me (al-Haq's field representative in London), "for the unhappy ending of al-Haq's enforcement project." 154

As it happened, by the end of the summer, Fateh Azzam-an active supporter of the Enforcement Project-returned from completing his LLM in the UK and took over as program coordinator, in which role he sought to review this decision and to revive discussions with al-Haq's board. But other challenges were also presenting themselves in the organization, and the new board resigned when the staff refused to accept its proposals for a new structure examined in chapter $7 .{ }^{155}$ Azzam organized a vote among staff on whether the Enforcement Project should stay with al-Haq; the vote, according to Azzam, was for keeping the project, but only by a very narrow margin. After five years, support for the project among the staff was seriously divided, and Shammas and I left al-Haq. ${ }^{156}$ Institutional communications were maintained through Azzam's involvement in the advisory board of CIHRE.

Reflecting on the "unhappy ending" of the project at al-Haq, Nina Atallah's observation sums up the thoughts also of others from the time who remain engaged in human rights work: "Maybe it wasn't its time for us at the organization, because now we all think it's important," she says, "but in its time it was obscure, and things that are obscure are usually uncomfortable. I myself couldn't make up my mind." Issam Younis, a member of the Enforcement Team and subsequently founder and director of Al Mezan human rights organization in Gaza, agrees that "perhaps al-Haq didn't appreciate the value of the Project, but the team's work was 
important; today that's what we organizations do."157 The invocation of third-party state responsibilities through targeted direct interventions and communications to a range of third-party (state and nonstate) actors-often by a group of Palestinian organizations - is now standard. In more recent years, al-Haq employed an EU advocacy officer based in its Netherlands and Brussels office and has currently a section on its website dedicated to this work.

As for the al-Haq Enforcement Project, despite the complicating factors set out above, it was, strangely, very much of its time. It sprang from a growing realization of the impossibility of accessing local remedies or protections, and the insistence that, logically, the law couldn't let things stop there. In the late 1990s al-Haq, having passed through the turbulent years of Oslo and its aftermath and lost nearly all of its staff in an organizational crisis, returned to the legacy of its project. In 1998 it formed a working group for enforcement of the Fourth Geneva Convention with four other NGOs. The next year, in a Newsletter article about the Conference of High Contracting Parties convened in July 1999, al-Haq laid claim, possibly for the first time, to the organization's contribution to this work: "al-Haq pioneered the movement to raise the issue of Israel's refusal to apply the Fourth Geneva Convention at the level of the international community." ${ }^{158}$ The annual report issued by al-Haq (by then under the leadership of Randa Siniora) on the first year of the second intifada, In Need of Protection (2002), in its final section developed the arguments and implications of the provisions on grave breaches and the Article 1 obligation, and formally thanked Shammas, "whose work greatly informed our own." 